\title{
ÅrSBERETNING 2006
}

\section{Dansk Kriminalistforening}

Foreningens formand er direktør William Rentzmann og sekretær og kasserer er advokat Bjørn Høberg-Petersen. Bestyrelsen består endvidere af professor Flemming Balvig, professor Ulla Bondeson, rigsadvokat Henning Fode, dommer Peter Garde, professor Vagn Greve, politimester Lars Rand Jensen, overlæge Peter Kramp, forskningschef Britta Kyvsgaard, professor Gorm Toftegaard Nielsen, departementschef Michael Lunn, landsdommer Ina Steincke og fængselsinspektør Lene Møller-Nielsen.

Foreningens æresmedlemmer er professor, dr. jur. Knud Waaben og højesteretssagfører Jon Palle Buhl (som desværre afgik ved døden dagen før årsmødet i 2007).

Årsmødet i foreningen fandt sted den 28. februar 2006. Efter generalforsamlingen holdt advokat Gunnar Homann oplæg om Udvisning som strafferetlig sanktion.

Dansk Kriminologisk Selskab, der er et datterselskab til Dansk Kriminalistforening, arrangerede i foråret 2005 tre møder, hvoraf det første allerede var blevet afholdt før generalforsamlingen fandt sted.

Den 1. februar afholdt selskabet et møde i samarbejde med DUK, Diplomuddannelse i Kriminologi, og Det Kriminalpræventive Råd. På mødet fortalte judge George Leventhal om Brooklyn Domestic Violence Court. Den 27. marts indledte fhv. landsdommer H.H. Brydensholt om Behandling af krigsforbrydelser og andre internationale forbrydelser. Den 2. maj fortalte politiadvokat Carsten Egeberg Christensen, advokat Steen Bech og fhv. dommer Niels Viltoft om Granser for aftaler med anklagemyndigheden.

I efteråret 2006 var der to møder i selskabet: Den 23. oktober fortalte Karin Sten Madsen, Center for Voldtægtsofre, om Hvor ku' du gøre det? - samtaler efter voldtcegt. I selskabets sidste arrangement den 27 . november indledte Tapio Lappi-Seppälä om Why do Nordic countries have low prisoner rates compared to other European countries?

Dansk Selskab for International Strafferet og EU-ret, der også er et datterselskab til Dansk Kriminalistforening har i samarbejde med Juridisk Institut, Syddansk Universitet afholdt tre møder i det forløbne år.

Den 7. februar indledte kommitteret Nina Holst Christensen, Justitsministeriet, om Hvor langt er strafferetten på vej mod overstatsligt samarbejde? Den 6. april fortalte kontorchef Kristian Korfits Nielsen, Justitsministeriet, om Arrestordre og bevissikring - en status. I samarbejde med Retssikkerhedsfonden blev der afholdt møde den 4. december 2006 om Terrorlisterne og restssikkerheden: 